Nigerian Journal of Physiological Sciences 24 (2): 111 -116 @Physiological Society of Nigeria, 2009

Available online/abstracted at http://www.bioline.org.br/np; www.ajol.info/journals.njps; www.cas.org

\title{
ANTISPASMODIC AND SPASMOLYTIC EFFECTS OF METHANOLIC EXTRACT FROM SEEDS OF GARCINIA KOLA ON ISOLATED RAT SMALL INTESTINE
}

\author{
P. M. UDIA, V. B. BRAIDE AND D. U. OWU ${ }^{1}$ \\ Departments of Pharmacology and Physiology ${ }^{l}$, College of Medical Sciences, University of Calabar, \\ Calabar, Nigeria E-mail: udishiet@yahoo.com. Tel: +2348037748430
}

Summary: The antispasmodic and spasmolytic effects of methanolic extract of seeds of Garcinia kola Heckel were studied on smooth muscle preparations in vitro. The influence of the extract on rat duodenum, jejunum and ileum was investigated using acetylcholine and barium chloride as agonists. The extract exhibited dose-dependent antispasmodic effects on contractions induced by acetylcholine, and dose-dependent spasmolytic effects on spasms induced by cumulatively increased concentrations of acetylcholine and barium chloride. The graded log concentration- response curves for acetylcholine were non-parallel but shifted to the right in the presence of the extract. It is concluded that the Garcinia kola extract inhibits smooth muscle activity via other mechanisms but not involving neither cholinergic nor adrenergic receptor interaction.

Key words: Garcinia kola, small intestine, acetylcholine, antispasmodic effect.

\section{Introduction}

The seeds of Garcinia kola_Heckel (FamGuttiferae) were obtained from a tree which grows in the wild but are sometimes cultivated in the southern part of Nigeria. It is locally called "bitter kola". These seeds are edible and are consumed as adjuvant to the true kola (Cola nitida) and also for medicinal purposes (Daziel, 956; Braide, 1989). Garcinia kola seeds are used in Nigerian traditional medicine for the treatment of asthma, diarrhoea, gastroenteritis, menstrual cramps and as antidote for poisons (Braide, 1989; Orie and Ekon, 1993; Kabungu et al, 1987). G. kola seeds have bronchodilation effect on tracheal smooth muscle cells in humans (Orie and Ekon, 1993). Though preliminary phytochemical studies had indicated that the seeds of G. kola lack caffeine (Eka, 1983), it contains alkaloids and biflavonoids (Braide, 1989; Hussain and Waterman, 1982; Iwu, 1982). Alkaloid and biflavonoid fractions from these seeds exhibit antagonistic effects on drug-induced spasms on rat duodenum and uterus and on guinea pig ileum (Braide, 1989). Orie and Ekon (1993) have demonstrated the inhibitory effects of $G$. kola seeds on tracheal smooth muscle in humans. Other workers have investigated the effects of flavonoids of other plants and of synthetic flavonoids on some smooth muscle activity of experimental animals (Ogata et al, 1993; Belluco et al, 1993; Di Carlo et al, 1993). Biflavonoids from $G$. kola have anti-inflammatory properties (Braide, 1993), is a natural antioxidant (Olatunde et al 2002, Terashima et al, 2002; Olatunde et al, 2002b; Farombi et al, 2007) and is hepatoprotective (Adaramoye and Adeyemi, 2006; Farombi et al, 2009;
Adaramoye et al, 2008) Extracts from G. kola seeds have been reported to alter oestrous cycle, inhibit ovulation, induce teratogenicity (Akpantah et al, 2005), and to be non-toxic to erythrocytes even at high dose ranges (Esomonu et al, 2005). In the search for alternatives to synthetic hypoglycaemic agents, Adaramoye and Adeyemi (2006) reported antidiabetic and hypolipidaemic effects of fractions of Kolaviron, (a G. kola seed extract) in streptozotocin (STZ)-diabetic rats. These reports are indicative of the ability of the active components of this species of kola and of flavonoids from other plants (Agil et al, 1994) to arrest inflammation and/or smooth muscle hypermotility and of other ailments when used in traditional medicine.

The objective of this study is to analyze the influence of the methanolic extract of G. kola seeds on the contractile responses of the rat intestine to spasms induced by acetylcholine and barium chloride in order to elucidate possible mechanism of action of this species of kola that is used in traditional herbal medical practice.

\section{Materials and methods \\ Plant extract}

The seeds of the plant, purchased from local markets in Calabar, Cross River State of Nigeria, were chopped into small pieces after removing the testa, and ground to a paste. The ground material was dried in an oven at a temperature of $40^{\circ} \mathrm{C}-60^{\circ} \mathrm{C}$. The dried powder $(300 \mathrm{~g})$ was defatted twice with two litres of petroleum ether and was then Soxhlet extracted using methanol. A brownish solid paste was obtained. The percentage yield of $10.5 \%$ was 
obtained. The extract was stored at $4^{\circ} \mathrm{C}$ until further use.

Animals

Adult Albino rats weighing $180-250 \mathrm{~g}$ were obtained from the animal house of the Department of Pharmacology, University of Calabar for the study. They were kept in animal house at room temperature of $30 \pm$ $2.0^{\circ} \mathrm{C}$ in a 12 -hour light/dark cycle. They were fed ad libitum with normal rat chow obtained from Livestock feeds Aba, Nigeria and had access to tap water. The animals were fasted for 18-hour prior to experiment and were sacrificed by stunning. The abdominal region of each animal was opened by midline incisions and the duodenum, jejunum and ileum were quickly removed and placed in Tyrode solution (PSS), (composition in $\mathrm{g} / \mathrm{l}$ : $\mathrm{NaCl}, 8.00 ; \mathrm{KCl}, 0.20 ; \mathrm{CaCl}_{2}, 0.20 ; \mathrm{MgCl}_{2}$, 0.10; $\mathrm{NaH}_{2} \mathrm{PO}_{4}, 0.05 ; \mathrm{NaHCO}_{3}, 1.00$; glucose, 2.00), (Rodriguez et al, 1986). Tubular segments $(2-3 \mathrm{~cm}$ long) were cut from the duodenum, jejunum and ileum and were suspended in PSS at $37^{\circ} \mathrm{C}$ under the conditions mentioned in Table 1 and continually aerated with atmospheric air.

Each tissue preparation, under the conditions mentioned in Table 1, was allowed to equilibrate for a period of 45-60 minutes under a resting tension of $1-1.5 \mathrm{~g}$ before it was challenged with the methanolic extract or G. kola seed (GKE) or agonist drug. The druginduced responses or the spontaneous rhythmic contractions of the tissues were recorded isotonically on graph paper with a slow moving kymograph (C.F. Palmer LTD., England.)

\section{Determination of antispasmodic effects}

Various concentrations $\left(1 \times 10^{-5}-3 \times 10^{-3}\right.$ $\mathrm{g} / \mathrm{ml}$ ) of GKE were added to the bathing solution containing the tissue, and the responses of the tissue were recorded. In different tissue preparations, the experiments were performed using graded doses of acetylcholine (ACh) $\left(1 \times 10^{-6} \mathrm{M}-1 \times 10^{-4} \mathrm{M}\right)$. After obtaining responses to acetylcholine (ACh) stimulation, the experiments were repeated after pre-incubation with various concentrations of GKE $\left(2 \times 10^{-5}-2 \times 10^{-4}\right.$ $\mathrm{g} / \mathrm{ml}$ ). From the results, log-concentrations against the amplitude of contractions (expressed as percentage of maximal control contractions) were constructed for $\mathrm{ACh}$ in the presence of two dose levels of GKE. From each of these curves, the $\mathrm{EC}_{50}$ and the $\mathrm{E}_{\max }$ values of $\mathrm{ACh}$ were estimated for control responses and in the presence of different concentrations of GKE.

Spasmolytic effects of the extract on drug induced contractions

Each tissue was prepared as described above and was bathed with normal Tyrode solution. The preparation was then challenged with cumulatively increased concentrations of $\mathrm{ACh}\left(5 \times 10^{-7}-2.5 \times 10^{-6} \mathrm{M}\right)$ or $\mathrm{BaCl}_{2}\left(2 \times 10^{-4}\right.$ $\left.-6 \times 10^{-4} \mathrm{M}\right)$ added to the bath fluid. The percentage inhibitions of drug-induced contractions were estimated for various concentrations of $\mathrm{GKE}$ and $\mathrm{IC}_{50}$ of $\mathrm{GKE}$ was calculated from the inhibition curve.

\section{Drugs}

Acetylcholine, barium chloride and propranolol were obtained from Sigma Chemical Co, MO, USA while prazosin was purchased from Allen and Hanburys LTD, London. Other chemicals were obtained from Sigma Chemical Co, MO, USA. All drugs were dissolved in deionized distilled water while stock solutions $(100 \mathrm{mg} / \mathrm{ml})$ of the extract were prepared by dissolving $1 \mathrm{~g}$ of the extract in $1 \mathrm{ml}$ of diethylether and the volume made up to $10 \mathrm{ml}$ with distilled water.

\section{Result Analysis}

The $\mathrm{EC}_{50}$ values were calculated from the $\log$ concentration-response curves and confirmed by means of logit representation from a plot of $\log \left(\mathrm{E}_{\mathrm{A}} / \mathrm{E}_{\max }-\mathrm{E}_{\mathrm{A}}\right)$ against $\log$ concentration $(\mathrm{M})$. The $\mathrm{EC}_{50}$ is the value in the abscissa when the $\log \left(\mathrm{E}_{\mathrm{A}} / \mathrm{E}_{\max }-\mathrm{E}_{\mathrm{A}}\right)$ equals zero (Rodriguez et al, 1996).

\section{Statistical analysis}

All values were expressed in mean \pm SEM. The data were statistically analyzed using student's t-test. A P-value of 0.05 was considered significant.

\section{Results}

The extract of $G$. kola elicited contraction of the isolated rat ileum at concentrations of 2 $\mathrm{x} 10^{-6}-2 \times 10^{-4} \mathrm{~g} / \mathrm{ml}$. Increased concentrations of the extract in these preparations at these dose ranges produced decreases in heights of contractions, such that $1 \times 10^{-5}, 2 \times 10^{-5}$ and $4 \times 10^{-5} \mathrm{~g} / \mathrm{ml}$ produced contractions in a descending order (Fig. 1). These effects were abolished by pre-incubation with $2 \times 10^{-6} \mathrm{~g} / \mathrm{ml}$ of GKE. However, the extract produced antispasmogenic and antispasmodic effects at higher concentrations in the presence of spasmogens, acetylcholine or barium chloride (Figs.2, 3; Tables 2 and 3). 
Table 1: Experimental conditions in the rat tissue preparation

\begin{tabular}{|c|c|c|c|}
\hline$\underset{(a)}{\text { Experimental condition }_{(a)}}$ & Duodenum & Jejunum & Ileum \\
\hline Bath volume (ml) & 10 & 10 & 50 \\
\hline $\begin{array}{c}\text { Speed of recording } \\
\text { paper }(\mathrm{mm} / \mathrm{sec})\end{array}$ & 0.063 & 0.063 & 0.016 \\
\hline $\begin{array}{l}\text { Equilibration time } \\
\text { (min) }\end{array}$ & 45 & 45 & 60 \\
\hline $\begin{array}{l}\text { Interval between doses } \\
\text { (min) }\end{array}$ & 1.5 & 1.5 & 5 \\
\hline Dosing method & Cumulative & Cumulative & Graded \\
\hline $\begin{array}{l}\text { Agonist (concentration } \\
\text { range) }\end{array}$ & $\begin{array}{l}\mathrm{BaCl}_{2}\left(2-3 \times 10^{-4} \mathrm{M}\right) \\
\operatorname{Ach}\left(5 \times 10^{-7}-2.9 \times 10^{-6} \mathrm{M}\right)\end{array}$ & $\begin{array}{l}\mathrm{BaCl}_{2} \\
\left(2-6 \times 10^{-4} \mathrm{M}\right)\end{array}$ & $\begin{array}{l}\mathrm{ACh} \\
\left(5 \times 10^{-6}-2.9 \times 10\right. \\
\left.{ }^{4} \mathrm{M}\right)\end{array}$ \\
\hline
\end{tabular}

(a): All tissues were maintained at $37^{\circ} \mathrm{C}$ in Tyrode solution and aerated with atmospheric air. (b): Isotonic recording, $\mathrm{Ach}=$ acetylcholine, $\mathrm{BaCl} 2=$ Barium chloride

Table 2: Effect of adrenoceptor antagonists on the relaxant effect of GKE on Ach-induced contractions on guinea pig ileum

\begin{tabular}{llll}
\hline Drugs $^{+}($Max. conc. $)$ & $\begin{array}{l}\text { Tissue response } \\
(\mathrm{mm})\end{array}$ & t-value & $\begin{array}{l}\text { \% Inhibition of } \\
\text { contraction }\end{array}$ \\
\hline $\mathrm{ACh}\left(5 \times 10^{-7} \mathrm{M}\right)$ & $38.8 \pm 0.6$ & - & - \\
\hline $\begin{array}{l}\mathrm{GKE}\left(3 \times 10^{-4} \mathrm{~g} / \mathrm{ml}\right) \\
+\mathrm{ACh}\left(5 \times 10^{-7} \mathrm{M}\right)\end{array}$ & $35.3 \pm 0.5$ & $4.481^{*}$ & $9.0 \pm 1.3$ \\
\hline $\begin{array}{l}\text { Pro. }\left(1.6 \times 10^{-2} \mathrm{mg} / \mathrm{ml}\right) \\
+\mathrm{GKE}\left(3 \times 10^{-4} \mathrm{~g} / \mathrm{ml}+\mathrm{ACh}\left(5 \times 10^{-7} \mathrm{M}\right)\right.\end{array}$ & $34.3 \pm 0.4$ & $6.241^{*}$ & $11.6 \pm 1.3$ \\
& & & \\
\hline $\begin{array}{l}\text { Praz. }\left(4 \times 10^{-4} \mathrm{mg} / \mathrm{ml}\right) \\
+\end{array}$ & $34.9 \pm 0.7$ & $4.229^{*}$ & $10.1 \pm 1.8$ \\
$\mathrm{GKE}\left(\left(3 \times 10^{-4} \mathrm{~g} / \mathrm{ml}\right)+\mathrm{ACh}\left(5 \times 10^{-7} \mathrm{M}\right)\right.$ & & & \\
\hline
\end{tabular}

$+\overline{\text { Listed in order of introduction. Figures in brackets represent drug concentrations in organ bath. } *=P<0.01}$ (Compared with control $).$ ACh $=$ acetylcholine, $G K E=G$. kola extract, Pro. $=$ Propranolol, Praz. $=$ Prazosin Results show mean \pm SEM of 4 observations.

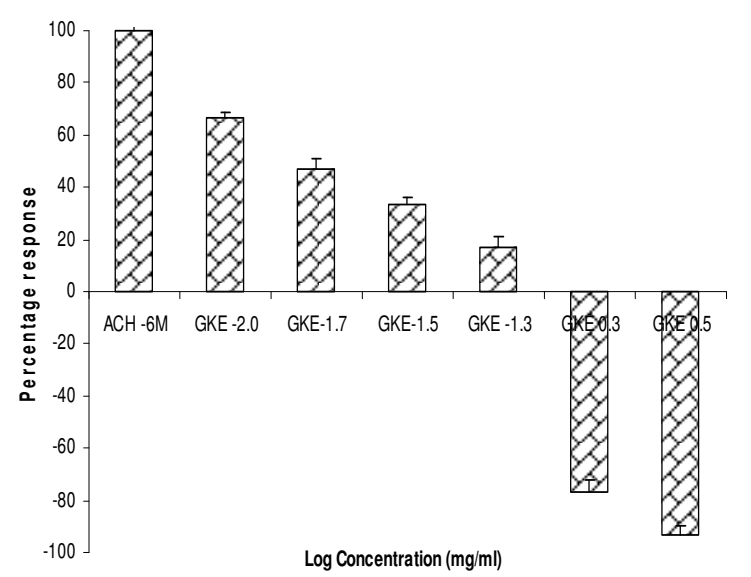

Fig. 1: Effect of Garcinia kola extract on the motility of rat ileum

Fig. 1: Effect of Garcinia kola extract on the motility of rat ileum

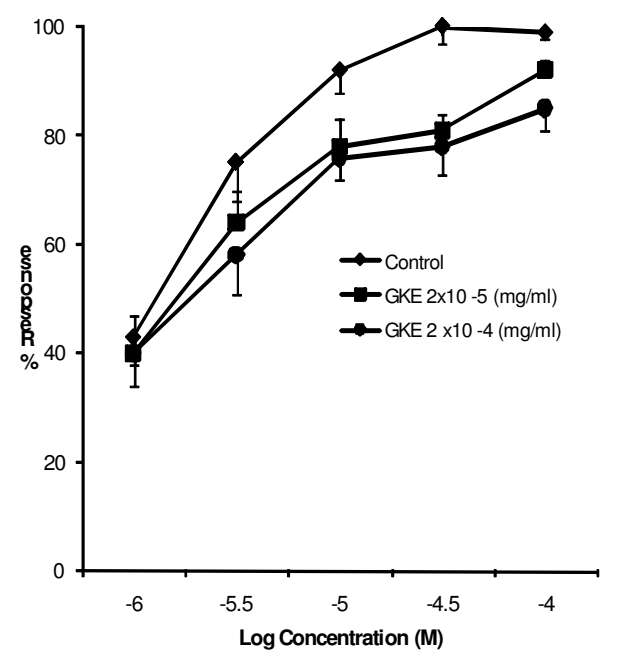

Fig. 2: Effect of various doses of GKE on Achinduced contraction on rat ileum. 
Table 3: $\mathrm{BaCl}_{2}$ induced contractions on rat duodenum and the dose-dependent Spasmolytic effect of GKE on $\mathrm{BaCl}_{2}$ induced contractions

\begin{tabular}{ccll}
\hline $\mathrm{BaCl}_{2}(\mathrm{M})$ & $\begin{array}{l}\text { Tissue } \\
\text { response }\end{array}$ & GKE $(\mathrm{g} / \mathrm{ml})$ & $\begin{array}{l}\text { \% Inhibition of } \\
\text { max.Responses }\end{array}$ \\
\hline $2 \times 10^{-4}$ & $30.0 \pm 4.0$ & $1 \times 10^{-4}$ & $30.1 \pm 7.2$ \\
\hline $4 \times 10^{-4}$ & $54.6 \pm 2.2$ & $2 \times 10^{-4}$ & $52.6 \pm 4.6$ \\
\hline $6 \times 10^{-4}$ & $72.9 \pm 4.0$ & $1 \times 10^{-3}$ & $76 \pm 5.6$ \\
\hline $8 \times 10^{-4}$ & $100 \pm 4.0$ & $2 \times 10^{-3}$ & $100 \pm 4.0$ \\
\hline
\end{tabular}

* Results show mean \pm SEM of 6 observations
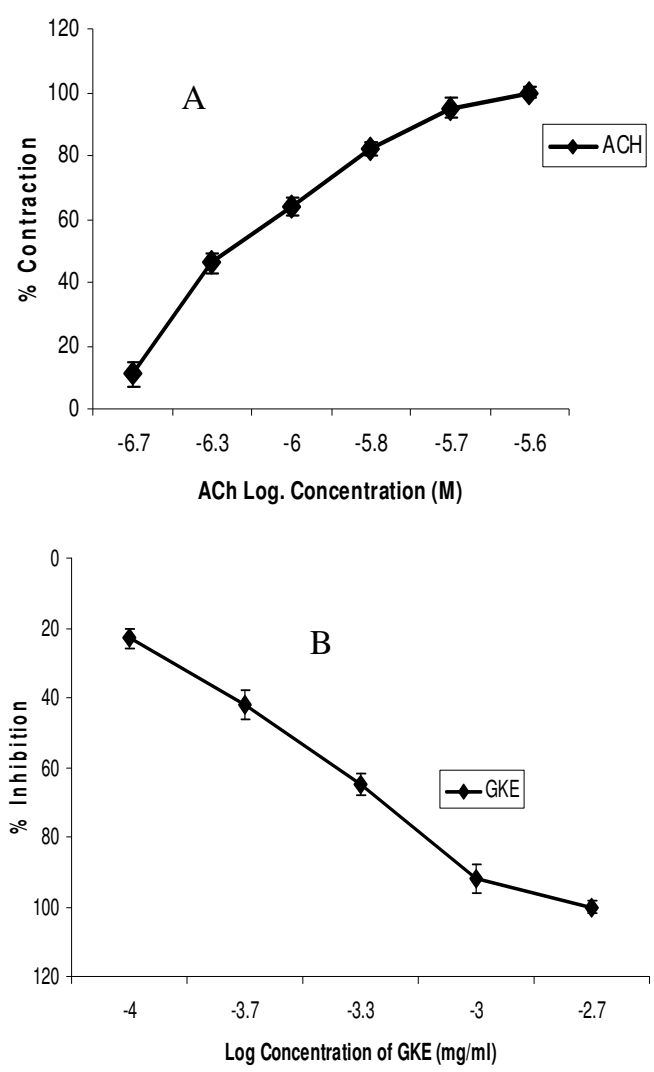

Fig. 3: (a) Cumulative log. concentration.response curve for Ach on rat duodenum (b) Inhibition curve of GKE on Ach-induced contractions on rat duodenum.

Antispasmodic action

Addition of the G. kola extract (GKE: 2 x $\left.10^{-5}-2 \times 10^{-4} \mathrm{~g} / \mathrm{ml}\right)$ to the isolated rat ileum preparation shifted the log dose-response curves of acetylcholine (Ach) induced contractions to the right in a dose-dependent manner (Fig. 2). Within the dose ranges of ACh used (Table 1), GKE affected both the $\mathrm{EC}_{50}$ and the $\mathrm{E}_{\max }$ values. The $\mathrm{EC}_{50}$ control was $1.3 \times 10^{-6} \mathrm{M}$ of $\mathrm{ACh}$, the $\mathrm{EC}_{50}$ in the presence of $2 \times 10^{-5} \mathrm{~g} / \mathrm{ml}$ of GKE was $1.6 \times 10^{-}$ ${ }^{6} \mathrm{M}$ and the corresponding $\mathrm{E}_{\max }$ was $92 \%$.
Increasing the concentration of GKE to 2 $\times 10^{-4} \mathrm{~g} / \mathrm{ml}$ produced an $\mathrm{EC}_{50}$ of $2.0 \times 10^{-6} \mathrm{M}$ and $E_{\max }$ value of $85 \%$ when compared with control.

In another set of experiments using guinea pig ileum, pre-administration of propranolol $\left(1.6 \times 10^{-2} \mathrm{mg} / \mathrm{ml}\right)$, a beta-adrenergic receptor antagonist, or prazosin $\left(4 \times 10^{-4} \mathrm{mg} / \mathrm{ml}\right)$, and alpha-adrenergic receptor antagonist, failed to abolish the relaxant effect of GKE on Ach induced contractions (Table 2).

Spasmolytic effects of GKE on Ach and $\mathrm{BaCl}_{2}$ -induced spasms

GKE exhibited dose-dependent spasmolytic effects on spasms induced by cumulative increased concentrations of Ach on rat duodenum (Fig. 3). At a dose of $1 \times 10^{-4}$ $\mathrm{g} / \mathrm{ml}$, GKE exhibited $23 \pm 3 \%$ inhibitory effect on Ach $\left(2.5 \times 10^{-6} \mathrm{M}\right)$ induced contraction; at a dose of $1 \times 10^{-3} \mathrm{~g} / \mathrm{ml}$, the inhibitory effect was $92 \pm 4 \%(n=6)$.

GKE equally suppressed, in a dosedependent manner, contractions induced by cumulative addition of non-specific smooth muscle stimulant, barium chloride $\left(\mathrm{BaCl}_{2}\right)$, on the rat duodenum (Table III). On rat duodenum, the addition of $1 \times 10^{-4} \mathrm{~g} / \mathrm{ml}$ of GKE resulted in $30.1 \pm 7.2 \%$ inhibitory effect on $\mathrm{BaCl}_{2}$ induced contraction, whereas a dose of $2 \times 10^{-3} \mathrm{~g} / \mathrm{ml}$ GKE inhibited $\mathrm{BaCl}_{2}$ induced contractions by $100 \pm 4 \%$ (Table III; $n=6$ ). A similar trend was observed in experiments involving rat jejunum.

\section{Discussion}

The results obtained in the present investigation show that the methanolic extract of the seeds of Garcinia kola (GKE) has a biphasic action on contractility of intestinal smooth muscle cells. It induces contraction at low doses and causes relaxation at high doses. This spasmogenic effect at low doses may be through direct action on intestinal mucosa, but not a partial agonistic effect or a depolarizing blockage action. GKE diminished the responses of $\mathrm{ACh}$ and $\mathrm{BaCl}_{2}$ on rat duodenum, 
jejunum and ileum in a dose-dependent manner. It has been reported that G. kola contains biflavonoids (Adaramoye and Adeyemi, 2006b) and plants containing biflavonoids/flavonoids possess inhibitory effects on smooth muscle activity (Kabangu et al, 1987; Orie and Ekon 1993 and Di Carlo et al 1993). The fact that the $\mathrm{EC}_{50}$ value of $\mathrm{ACh}$ was significantly increased in the presence of the extract, while its $\mathrm{E}_{\max }$ diminished coupled with non-parallel shift of the dose-response curves, suggests that some components (alkaloids or flavonoids) of the extract are nonspecific inhibitors of smooth muscle activity. There was no evidence that the extract was interacting with specific autonomic receptors. Further evidence supporting non-specific interaction was based on the observation that on the already contracting gastrointestinal smooth muscle in response to agonist drugs, GKE exhibited rapid dose-dependent spasmolytic effect on spasms induced by ACh and $\mathrm{BaCl}_{2}$, which are specific and non-specific smooth muscle spasmogens, respectively. Adrenergic blockade by prazosin (an alphaadrenergic receptor antagonist) or propranolol (a beta-adrenergic receptor antagonist) failed to attenuate the inhibitory effect of GKE on ACh induced contractions. The failure of enhancement of ACh induced contractions in the presence of adrenergic receptor antagonists, when GKE was administered, indicated that GKE was not eliciting its smooth muscle relaxant effect via activation of any adrenergic receptors.

Braide (1989), Orie and Ekon (1993) and Di Carlo et al (1993) had suggested that $G$. kola seeds and/or extracts from it (alkaloids or biflavonoids) reduced tone and strength of contraction of smooth muscles in the presence of $\mathrm{ACh}, \mathrm{BaCl}_{2}$ or histamine. It is concluded that the antispasmodic and spasmolytic effects of methanolic extract of the seeds of G. kola (GKE) on smooth muscle activity of gastrointestinal tract are mediated via nonspecific mechanisms.

\section{Acknowledgement}

The authors are grateful to C. M. Udia of the Department of Estate Management CRUTECH, Calabar, Nigeria, for financial assistance, and Dr F. V. Udoh of the Department of Pharmacology, University of Calabar, Calabar, Nigeria, for technical assistance.

\section{References}

Adaramoye, O. A. and Adeyemi, E. O. (2006). Hepatoprotection of D-galactosemineinduced toxicity in mice by purified fractions from Garcinia kola seeds. Basic \& Clin. Pharmacol. \& Toxicol. 98: 135141.

Adaramoye, O. A. and Adeyemi, E. O. (2006b). Hypoglycaemic and hypolipidaemic effects of fractions from Kolaviron, a biflavonoid complex from Garcinia kola in streptozotocin- induced diabetes mellitus rats. J. Pharm. and Pharmacol. 58: 121-128.

Adaramoye, O. A., Farombi, E. O., Nssien, M., Idowu, S. O., Ademowo, O, G. and Adeyemi, E, O. (2008). Hepatoprotective activity of purified fractions from Garcinia kola seeds in mice intoxicated with carbon tetrachloride. J Med Food. 11(3): 544-50.

Agil, M., Khan, I. Z., Ahmed, M. B. and Ishikura, N. (1994). A Novel Glycoside 5,6,7 - Trimethoxy Flavone 4'-B-B-DGlycoside from Buchnera hispida. Disc. and Innov. 6: 343 - 345.

Akpantah, A. O., Oremosu, A. A., Noronha, C. C., Ekanem, T. B. and Okanlawon, A. O. (2005). Effects of Garcinia kola seed extract on ovulation, ocetrous cycle and foetal development in cyclic female Sprague-Dawley rats. Niger. J. Physiol. Sci. 20(1-2): $58-62$.

Belluco, P., Gaion, R. M., Marangno, I. and Darigo, P. (1993), Quercetin and vascular spasm. Pharmacol. Res. 27: 71 - 72.

Braide, V. B. (1989). Antispasmodic extracts from seeds of Garcina kola. Fitoterapia, LX: $123-129$.

Braide, V. B. (1993): Anti-inflammatory effect of kolaviron, a biflavonoid of Garcinia kola seeds. Fitoterapia; LXIV: $433-36$.

Daiziel, J. M. (1956). Useful Plants of Tropical Africa. Crown Agents, London.

Di Carlo, G., Autoye, G., Mascolo, N., Meli, R. and Carpasso, F. (1993). Effects of flavonoids on small intestinal transit in mice. Pharmacol. Res. 27:37 - 38.

Eka, O. U. (1986). Isolation of pure caffeine from Cola nitida and chemical composition of Garcinia kola. Niger. J. Physiol. Sci. 10: 94 - 98.

Esomonu, U. G., EL-Taalu, A. B., Amuka, J. A., Ndodo, N. D., Salim, M. A. and Atiku, M. K. (2005). Effect of ingestion of ethanol extract of Garcinia kola Seed on erythrocytes in Wistar rats. Niger. J. Physiol. Sci. 20(1-2): 30-32.

Farombi, E. O, Shrotriya, S. and Surh, Y. J. (2009). Kolaviron inhibits dimethyl nitrosamine-induced liver injury by suppressing COX-2 and iNOS expression 
via NF-kappaB and AP-1. Life Sci. 84(56): 149-55.

Farombi, E. O., Abarikwu, S. O., Adedara, I. A. and Oyeyemi, M. O. (2007). Curcumin and kolaviron ameliorate di-nbutylphthalate-induced testicular damage in rats. Basic Clin Pharmacol Toxicol. 100(1): 43-48.

Hussain. R. A. and Waterman, P. G. (1982). Lactones, flavonoids and benzophones from Garcinia conrauna and Garcinia mianni. Phytochemistry, 21: 1393 - 1396.

Iwu, M. M. (1985). Antihepatotoxic constituents of Garcinia kola seeds. Experientia. 41: 699- 700.

Kabangu, L., Galeffi, C., Aonzo, E., Nicoletti, M. and Messana, L. (1987). New biflavone from the bark of G. kola. Planta Medica 11: 275 - 277.

Ogata, N., Baba, T. and Shibata, T. (1993). Demonstration of antidiarrheal and antimotility effects of wood creasote. Int. J. Expt. Clin. Pharmacol. 46: 173 - 180.

Olatunde, F. E., Hansen, M., Rain-Haren, P. and Dragsted, L. O. (2002). Commonly consumed and naturally occurring substances affect bio makers of oxidative stress and DNA-damage in healthy rats. Food Chem. Toxicol. 42: 1315 - 1322.

Olatunde, F. E., Akanni, O. O. and Emerole, G. O. (2002b). Antioxidant and scavenging activity of flavonoid extract (kolaviron) of Garcinia kola seeds. Pharmaceut. Biol. 40: 107 - 116.

Orie, N. N. and Ekon, E. U. A. (1993). The bronchodilator effect of Garcinia kola. East African Med. J. 70: 143 - 145.

Rodriguez, R., Lasheres, B. and Cenarruzabeitia, E. (1986). Pharmacological activity of Prunus spinosa on isolated tissue preparations. Planta Medica. 4: 256 - 259.

Terashima, K., Takaya, Y. and Niwa, M. (2002). Powerful antioxidant agents based on garcionic acid from Garcinia kola. Bioorg. Med. Chem. 10(5): 1619 - 1625.

Received: July 22, 2009

Accepted: November 20, 2009 